\title{
THE EFFECT OF LAPAROSCOPIC TUBAL DISCONNECTION OR LAPAROSCOPIC SALPINGECTOMY ON OVARIAN RESERVE.
}

\author{
By \\ Mohamed Ata Ahmed Emara, Ehab Hassanin Mohamad Hassanin and \\ Farid Ahmed Sayed Kassab \\ Department of Obstetrics and Gynecology, Faculty of Medicine, Al-Azhar University \\ Corresponding author: Mohamed Ata Ahmed Emara \\ Email: mohamedataemara@gmail.com
}

\begin{abstract}
Background: Fertility of a woman is the most important job in her life, thus preserving the elements of this fertility is much important. The biological age and ovarian reserve are of the most agonizing issues for women, especially in their late thirties and forties. The uterine tubal disconnection versus uterine tubal excision is usually indicated in subfertile patient suffering from tubal disease or indicated in surgical management of ectopic tubal pregnancy.

Objective: To study the effect of laparoscopic tubal disconnection or laparoscopic salpingectomy on ovarian reserve.

Patients and methods: This study is a prospective cohort study that was conducted at the Endoscopy Unit, Obstetrics and Gynecology Department, Al-Azhar University Hospitals, throughout the period from Oct. 2019 to Sep. 2020. It included 44 patients of the outpatient clinic with a diagnosis of tubal factor infertility or tubal ectopic pregnancy. 22 patients underwent laparoscopic proximal tubal disconnection, and 22 patients underwent laparoscopic salpingectomy. In both groups, basal antral follicle count (AFC) and mean ovarian volume (OVVOL) were evaluated by transvaginal sonography (TVS) before and 3 months after surgery.
\end{abstract}

Results: The mean of the basal AFC and mean OVVOL before and after laparoscopic tubal disconnection were the same suggesting no effect on ovarian reserve, while the mean AFC and OVVOL before and after laparoscopic salpingectomy were different. Both decreased, suggesting negative effect. It was insignificant negative difference in basal AFC and hardly significant negative difference in mean OVVOL.

Conclusion: Laparoscopic tubal disconnection does not affect ovarian reserve, while salpingectomy has a negative effect on ovarian reserve estimated by OVVOL three months after the surgical intervention.

Keywords: Laparoscopic tubal disconnection, Laparoscopic salpingectomy, Ovarian reserve, AFC, OVVOL. 


\section{INTRODUCTION}

Ovarian reserve is an estimate of the quantity and quality of remaining ovarian follicles. The number of viable follicles continues to decline throughout the reproductive years. Ovarian reserve which is a primary determinant of fertility is affected by genetic factors, reproductive age and operative procedures involving the ovary or its blood supply. Fallopian tubes are the female organs that transport the oocyte from the ovary to the uterus every ovarian cycle. In the presence of the sperm, the fallopian tubes transport the sperm towards the ovum, and transport the fertilized ovum towards the uterus for implantation. Anatomically, fallopian tubes are formed of 4 portions; interstitial part, isthmus, ampulla and infundibulum. Grossly, the whole tube is about $10 \mathrm{~cm}$ in length and $1 \mathrm{~cm}$ in diameter and situated within the broad ligament (Casanova et al., 2018).

Laparoscopic diagnosis and management of tubal disease is appreciable and invaluable. Laparoscopic tubal disconnection may be done for female sterilization or to manage pyosalpinx or hydrosalpinx, while laparoscopic salpingectomy is usually done to manage huge hydrosalpinx, tubal ectopic pregnancy or fallopian tube neoplasm. This is for example, not exclusively and doesn't rule out other rare conditions (Rustamov et al., 2016).

Due to the close anatomical association of vascular and nervous supply of the fallopian tube and the ovary, partial disruption of the ipsilateral ovarian blood supply is possible after unilateral or bilateral tubal surgery, then reducing the ovarian reserve. Recent studies recommend cautious use of electro cautery with resection very close to the actual tube to avoid damage to the medial tubal artery, and recommend leaving a portion of an adherent tube on the ovary rather than performing unnecessary radical salpingectomy (Lumely et al., 2018).

Ultrasonographic biomarkers (antral follicle count, ovarian volume and stromal blood flow) are good predictors of ovarian reserve. Trans-vaginal measurement of these markers is quick, accurate and cost effective. Basal antral follicle count (AFC) and mean ovarian volume (OVVOL) will be used in this study (Domingues et al., 2010 and Oner et al., 2015).

The aim of the present work was to study the effect of laparoscopic tubal disconnection or laparoscopic salpingectomy on ovarian reserve.

\section{PATIENTS AND METHODS}

This study was a prospective cohort study that was conducted at the Endoscopy Unit, Obstetrics and Gynecology Department, Al-Azhar University Hospitals, throughout the period from Oct. 2019 to Sep. 2020. It included 44 patients of the outpatient clinic with a diagnosis of tubal factor infertility or tubal ectopic pregnancy (Omurtag et al., 2012 and Webster et al., 2019).

Before enrolment, every patient was counselled about her case, management choices. Patients were informed about alternative approaches and chose what kind of surgical technique they wanted to receive. All patients had given written consents to share in the study.

\section{Inclusion criteria:}




\section{Gynecologic cases:}

- Female patient aging 20 30 years,

- $\mathrm{BMI} \leq 30$,

- Uterine tube disease, hydrosalpinx or pyosalpinx, confirmed by trans-vaginal sonography (TVS) and scanning by hysterosalpingography

(HSG).

\section{Obstetric cases:}

- Female patient aging 20 30 years,

- $\mathrm{BMI} \leq 30$,

- Tubal ectopic pregnancy diagnosed by serum pregnancy test and TVS, and scoring for surgical management.

\section{Exclusion criteria:}

- Age under 20 or above 30 years.

- Obesity (BMI > 30).

- Prior tubal surgery.

- Prior ovarian surgery.

- Poly cystic ovary.

- Ovarian cyst / mass measuring more than $10 \mathrm{~mm}$.

- Decreased ovarian reserve.

- Intraoperative diagnosis of concurrent conditions e.g. endometriosis.

- Any medical disorder (other than uterine tubal diseases) is excluded from the study e.g. diabetes.
All cases were counseled about their diagnoses, informed about alternative therapeutic approaches. For patients who agreed to laparoscopic surgery, bipolar diathermy was used cautiously to operate and to achieve hemostasis.

For patient with mild to moderate tubal insult, proximal tubal disconnection was performed, while in those with severe tubal insult or ectopic pregnancy; salpingectomy was done (Dreyer et al., 2016, Hamza, 2017 and Webster et al., 2019).

Patients were divided into 2 equal groups: Laparoscopic proximal tubal disconnection group, and laparoscopic salpingectomy group.

All patients were subjected to history taking, clinical examination and investigations [Trans-vaginal sonography (TVS), hysterosalpigography (HSG) (HSG scanning is considered within 3 months before surgery), serum pregnancy test (Qualitative and quantitative serum pregnancy test is considered within 48 hours before surgery), and routine basic investigations: Blood group (ABO-Rh), complete blood count (CBC), prothrombin time and activity (PT and PA), random blood glucose (RBG), liver function tests (LFTs) and kidney function tests (KFTs)].

After surgery, same-day discharge to home if the surgical procedure was uncomplicated and the patient is doing well during the postoperative recovery. If a significant amount of blood loss occurred, observation overnight to follow vital signs and serial blood counts. Broad spectrum antibiotic and analgesic medications were prescribed (Munro and Gomel, 2019). 
All patients were asked to return on day 3 of the third menstrual cycle after their surgery. A high resolution transvaginal examination was done using the ultrasound device equipped with a 7.5 $\mathrm{MHz}$ vaginal probe. Examination of both ovaries by $2 \mathrm{D}$ TVS was performed for assessment of the basal antral follicle count (AFC), and mean ovarian volume (OVVOL) regardless of the side of the operation (Abuhamad et al., 2014, Stephenson, 2015 and Frates, 2017).

Statistical analysis: Recorded data were analyzed using the statistical package for the social sciences software (SPSS, Inc.,
Chicago, Illinois, USA) version 20.0 /2011 for windows. Quantitative data were expressed as mean \pm standard deviation (SD). Qualitative data were expressed as frequency and percentage. Independent-samples t-test of significance was used when comparing between two means. Paired sample t-test of significance was used when comparing between related samples. The confidence interval was set to $95 \%$ and the margin of error accepted was set to $5 \%$. P-value $\leq$ 0.05 was considered significant.

\section{RESULTS}

There was no statistically significant difference between the two groups according to the baseline characteristics (Table 1).

Table (1): Range and Mean \pm SD descriptive statistic of baseline characteristics in both groups.

\begin{tabular}{|c|c|c|c|}
\hline $\begin{array}{ll} & \text { Groups } \\
\text { Parameters }\end{array}$ & $\begin{array}{c}\text { Laparoscopic tubal } \\
\text { disconnection } \\
(n=22)\end{array}$ & $\begin{array}{c}\text { Laparoscopic } \\
\text { salpingectomy } \\
(n=22)\end{array}$ & $\begin{array}{c}\text { p- } \\
\text { value }\end{array}$ \\
\hline $\begin{array}{l}\text { Age (years) } \\
\text { Mean } \pm \text { SD } \\
\text { Range }\end{array}$ & $\begin{array}{c}23.36 \pm 2.22 \\
20-\mathrm{a} 28\end{array}$ & $\begin{array}{c}22.91 \pm 2.45 \\
20-\mathrm{a} 29\end{array}$ & $>0.05$ \\
\hline $\begin{array}{l}\text { Weight }(\mathbf{k g}) \\
\text { Mean } \pm \text { SD } \\
\text { Range }\end{array}$ & $\begin{array}{c}72.73 \pm 5.33 \\
63-a 81\end{array}$ & $\begin{array}{c}74.00 \pm 4.50 \\
69-\mathrm{a} 86\end{array}$ & $>0.05$ \\
\hline $\begin{array}{l}\text { Height }(\mathbf{m}) \\
\text { Mean } \pm \text { SD } \\
\text { Range }\end{array}$ & $\begin{array}{l}1.58 \pm 0.05 \\
1.49-\mathrm{a} 1.65\end{array}$ & $\begin{array}{l}1.62 \pm 0.05 \\
1.55-\mathrm{a} 1.74\end{array}$ & $>0.05$ \\
\hline $\begin{array}{c}\text { BMI }\left[\mathbf{w t} /(\mathbf{h t})^{2}\right] \\
\text { Mean } \pm \text { SD } \\
\text { Range }\end{array}$ & $\begin{array}{c}28.60 \pm 1.09 \\
26.43-\mathrm{a} 29.91\end{array}$ & $\begin{array}{c}28.37 \pm 1.46 \\
23.94-\mathrm{a} 29.97\end{array}$ & $>0.05$ \\
\hline $\begin{array}{c}\text { Admission diagnosis } \\
\text { 1ry infertility } \\
\text { 2ry infertility } \\
\text { Ectopic pregnancy for laparoscopy } \\
\text { Total number of cases }\end{array}$ & $\begin{array}{l}18(81.8 \%) \\
4(18.2 \%) \\
0(0 \%) \\
22(100 \%)\end{array}$ & $\begin{array}{l}10(45.5 \%) \\
1(4.5 \%) \\
11(50 \%) \\
22(100 \%)\end{array}$ & \\
\hline
\end{tabular}


There was no statistically significant difference between the two groups according to the before basal AFC and the mean OVVOL. There was a statistically significant difference between the two groups according to the after mean OVVOL (Table 2).

Table (2): Range and Mean \pm SD descriptive statistic of the before and after basal AFC, and the mean OVVOL in both groups.

\begin{tabular}{|c|c|c|c|c|}
\hline \multicolumn{2}{|c|}{ Time of measurement } & $\begin{array}{c}\text { Laparoscopic } \\
\text { tubal } \\
\text { disconnection } \\
\text { group }(n=22)\end{array}$ & $\begin{array}{c}\text { Laparoscopic } \\
\text { salpingectomy } \\
\text { group }(n=22)\end{array}$ & p-value \\
\hline \multirow{2}{*}{$\begin{array}{c}\text { The before } \\
\text { surgery TVS } \\
\text { examination }\end{array}$} & $\begin{array}{c}\text { AFC } \\
\text { Mean } \pm \text { SD } \\
\text { Range }\end{array}$ & $\begin{array}{c}17.18 \pm 2.41 \\
14-21\end{array}$ & $\begin{array}{c}17.32 \pm 2.42 \\
14-22\end{array}$ & $>0.05$ \\
\hline & $\begin{array}{c}\text { Ovarian volume } \\
\text { Mean } \pm \text { SD } \\
\text { Range }\end{array}$ & $\begin{array}{l}10.21 \pm 1.43 \\
6.59-15.01\end{array}$ & $\begin{array}{c}10.22 \pm 1.43 \\
8.6-14.84\end{array}$ & $>0.05$ \\
\hline \multirow{2}{*}{$\begin{array}{c}\text { The before } \\
\text { surgery TVS } \\
\text { examination }\end{array}$} & $\begin{array}{c}\text { AFC } \\
\text { Mean } \pm \text { SD } \\
\text { Range }\end{array}$ & $\begin{array}{c}17.16 \pm 2.40 \\
14-20\end{array}$ & $\begin{array}{c}17.26 \pm 2.42 \\
14-21\end{array}$ & $>0.05$ \\
\hline & $\begin{array}{c}\text { Ovarian volume } \\
\text { Mean } \pm \text { SD } \\
\text { Range }\end{array}$ & $\begin{array}{c}10.20 \pm 1.43 \\
6.59-15.01\end{array}$ & $\begin{array}{c}10.10 \pm 1.41 \\
8.48-14.54\end{array}$ & $<0.05$ \\
\hline
\end{tabular}

t-Independent Sample t-test.

There was no statistically significant effect of laparoscopic tubal disconnection on basal AFC and mean OVVOL (before surgery compared to after surgery). Also there was a statistically significant

Table (3): Comparison between before surgery and after surgery according to basal AFC and mean OVVOL in laparoscopic tubal disconnection group and salpingectomy group.

\begin{tabular}{|c|c|c|c|c|c|}
\hline \multicolumn{2}{|c|}{$\begin{array}{r}\text { Time of } \\
\text { measurement }\end{array}$} & $\begin{array}{c}\text { Before } \\
\text { surgery } \\
(\mathbf{n = 2 2})\end{array}$ & $\begin{array}{c}\text { After } \\
\text { surgery } \\
(\mathbf{n = 2 2})\end{array}$ & Mean Diff. & $\begin{array}{c}\text { p- } \\
\text { value }\end{array}$ \\
\hline $\begin{array}{c}\text { Groups } \\
\text { Laparoscopic } \\
\text { tubal } \\
\text { Disconnection } \\
\text { group }\end{array}$ & AFC & $17.18 \pm 2.41$ & $17.16 \pm 2.40$ & $-0.02 \pm 0.07$ & $>0.05$ \\
\cline { 2 - 7 } & Ovarian volume & $10.21 \pm 1.43$ & $10.20 \pm 0.17$ & $-0.01 \pm 0.02$ & $>0.05$ \\
\hline $\begin{array}{c}\text { Laparoscopic } \\
\text { Salpingectomy } \\
\text { group }\end{array}$ & AFC & $17.32 \pm 2.42$ & $17.26 \pm 2.42$ & $-0.06 \pm 0.08$ & $>0.05$ \\
\cline { 2 - 7 } & Ovarian volume & $10.22 \pm 0.23$ & $10.10 \pm 0.15$ & $-0.12 \pm 0.18$ & $<0.05$ \\
\hline
\end{tabular}




\section{DISCUSSION}

Ovarian reserve is affected by multiple determinants; genetic variants, environmental factors, biological or reproductive age, diseases and surgeries. Ovarian reserve cannot be measured directly, the evaluation of ovarian reserve is difficult to carry out. The serum level of follicle-stimulating hormone (FSH) is a predictor of functional ovarian reserve, but its usefulness is limited considering that the vast majority of patients undergo monolateral surgery and the contralateral intact gonad may completely substitute for reduced function of the operated ovary (Sonya et al., 2012).

Many studies reported that basal antral follicle number (AFC) and mean ovarian volume (OVVOL) could be used as indicators of ovarian reserve. Some studies stated that basal AFC is the most accurate biomarker to assess female fecundity. Others stated that mean OVVOL strongly correlates with the number of non-growing follicles and is a useful factor in the indirect estimation of human ovarian reserve (Agrawal et al., 2014).

Most studies on the topic of ovarian reserve after pelvic surgery are provided by infertility centers and are consequently lacking fertile patients and randomized selection of patients.

The present study included both infertile patients and fertile patients but also limited by selecting patients needing the procedure. According to this study, laparoscopic excision of uterine tube may affect the ovarian reserve, compared with laparoscopic proximal tubal disconnection.
Mostly, this was attributed to the damage to the ovarian vascular system during laparoscopic electrocoagulation or thermal damage of surroundings. Our study also has demonstrated that laparoscopic salpingectomy adversely affected ovarian reserve. This negative effect was significant in ovarian volume and insignificant in antral follicle count, when measured on the third menstrual cycle. The study has demonstrated that laparoscopic proximal tubal disconnection did not affect ovarian reserve. All study cases were examined by $7.5 \mathrm{MHz}$ trans vaginal sonography. Basal AFC and mean OVVOL were measured on the $3^{\text {rd }}$ day of the menstrual cycle before surgery and on the $3^{\text {rd }}$ day of the third menstrual cycle after surgery.

\section{As regard to transvaginal ultrasound examinations:}

For the proximal tubal disconnection group, no difference was detected for the quantitative data between before and after surgery. On the $3^{\text {rd }}$ menstrual cycle follow-up visit, the counts and the diameters taken were nearly the same as before surgery, and the calculated data were the same.

For the salpingectomy group, a difference was detected for the quantitative data between before and after surgery. On the $3^{\text {rd }}$ menstrual cycle follow-up visit, the counts and the diameters taken were reduced than that before surgery; this negative effect was significant only in mean OVVOL and still insignificant in basal AFC.

On the $3^{\text {rd }}$ menstrual cycle follow-up visit in salpingectomy group, the basal AFC showed negative effect, which was statistically insignificant, while the mean 
OVVOL showed negative effect which was statistically significant if either compared to before surgery or compared to the tubal disconnection group.

In both groups, the basal AFC seems to be less affected than mean OVVOL (on the $3^{\text {rd }}$ month follow up visit).

This analysis of collected data suggested that proximal tubal disconnection has no appreciable effect on/ did not affect ovarian reserve measured by basal AFC and mean OVVOL while salpingectomy has negative effect, measured by basal AFC and mean OVVOL and significant only in mean OVVOL. According to this study, laparoscopic proximal tubal disconnection can completely preserve ovarian reserve (OR).

Our results were in agreement with the study of Rustamov et al. (2016) who studied the effect of salpingectomy, ovarian cystectomy and salpingooopherectomy on ovarian reserve. The analysis of retrospectively collected cross-sectional data suggests that neither salpingectomy nor ovarian cystectomy for cysts other than endometrioma has an appreciable effect on ovarian reserve determined by AMH, AFC and FSH. In contrast, salpingo-oopherectomy and ovarian cystectomy for endometrioma appear to have a significant detrimental impact on ovarian reserve. Our results were in agreement with this study regarding unaffected antral follicle count after salpingectomy, but our results were different regarding the following aspects: We restricted the population age between 20 and 30 years old instead of age range between 20 and 45 years old in the study of Rustamov et al. (2016). We have studied both tubal disconnection and salpingectomy groups, examined AFC and OVVOL, and then found that mean ovarian volume significantly reduced in salpingectomy group in the 3rd menstrual cycle follow up visit. We followed up our patients for a short equal period (only 3 months). We did not study the effect of ovarian cystectomy or salpingooopherectomy on ovarian reserve. We did not investigate FSH or AMH (Rustamov et al., 2016).

\section{CONCLUSION}

Laparoscopic tubal disconnection did not affect ovarian reserve, while salpingectomy has a significant negative effect on ovarian reserve, estimated by OVVOL three months after the surgical intervention.

\section{REFERENCES}

1. Abuhamad A, Chaoui R, Jeanty P, Paladini D and Walsh E (2014): Ultrasound in Obstetrics and Gynecology: A Practical Approach, 1st Edition, Pbl. GLOWM, UK, (1114): 212-320.

2. Agrawal A,Verma A, Agrawal S, Shukla RC, Jain M and Srivastava A (2014): Antral follicle count in normal (fertility-proven) and infertile Indian women, Indian $\mathrm{J}$ Radiol Imaging, 24(3): 297-302.

3. Casanova R, Chuang A, Goepfert A, Hueppchen N, Weiss P, Beckmann C, Ling F, Herbert W, Laube W and Smith R (2018): Beckmann and Ling's Obstetrics and Gynecology, 8th edition, Pbl. Wolters Kluwer, USA, 19,27,32: 412-436, 594-605, 688-703.

4. Domingues TS, Rocha AM and Serafini PC (2010): Tests for ovarian reserve; reliability and utility, Current 
Opinion Obstet Gynecol., 22(4): 271276.

5. Dreyer K, Lier MC, Emanuel MH, Twisk JW, Mol BW, Schats R, Hompes PGA and Mijatovic V (2016): Hysteroscopic proximal tubal occlusion Vs laparoscopic salpingectomy as a treatment for hydrosalpinges prior to IVF or ICSI, Hu Reprod., 31(9): 2005-2016.

6. Frates M (2017): Callen's Ultrasonography in Obstetrics and Gynecology, 6th Edition, Pbl. Elsevier, UK, 32: 956-960.

7. Hamza MA (2017): Comparative study between laparoscopic tubal disconnection and ultrasound guided tubal aspiration in the management of hydrosalpinx prior to ICSI, J Fertil Steril., 21(1): 30-35.

8. Lumely J, Craven J, Abrahams P and Tunstall R (2018): Baily and Love's Essential Clinical Anatomy, Pbl. CRC Press, USA, 9: 144-147.

9. Munro MG and Gomel V (2019): Reconstructive and Reproductive Surgery in Gynecology, 2nd Edition, Pbl. CRC Press, USA, 2: 527-580.

10. Omurtag K, Grindler NM, Roehl KA, Bates GW, Beltsos AN, Odem R and Jungheim ES (2012): How members of the Society for Reproductive Endocrinology and Infertility and Society of Reproductive Surgeons evaluate, define and manage hydrosalpinges, J Fertil Steril., 97(5): 1095-1100.

11. Oner G, Ulug P and Elmali F (2015): Ovarian reserve markers in unexplained infertility patients treated with clomiphene citrate during intrauterine insemination, Arch Med Sci., 11(6): 1250-1254.

12. Rustamov O, Krishnan M, Roberts S and Fitzgerald C (2016): Effect of salpingectomy, ovarian cystectomy and unilateral salpingo-oopherectomy on ovarian reserve, Gynecol Surg., 13: 173-176.

13. Sonaya M, Jhonson NA, Rosen MP, Sternfeld B, Cedars MI and Pera R (2012): Genitic variants and environmental factors associated with hormonal markers of ovarian reserve in Caucasian and African American women, Hum Reprod., 27(2): 594608.

14. Stephenson SR (2015): Diagnostic Medical Sonography: Obstetrics and Gynecology, 3rd Edition, Pbl. Wolters Kluwer, USA, 12: 285-286.

15. Webster K, Eadon H, Fishburn S and Kumar G (2019): Ectopic pregnancy and miscarriage: diagnosis and initial management, Summary of Updated NICE guidance, BMJ, 367: 1628316284. 


\section{تأثثر فصل قناة فالوب أو استئصسال قناة فالوب بالمنظار البطني على المئ

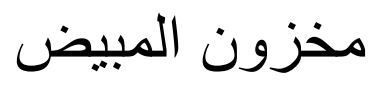

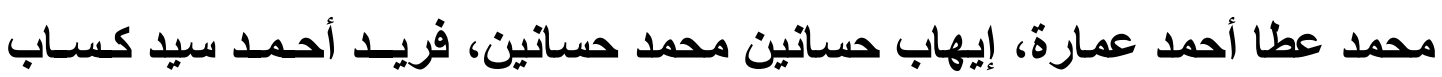
قسم التوليد وأمراض النساء ـ كلية الطب - جامعة الأزهر.

mohamedataemara@gmail.com

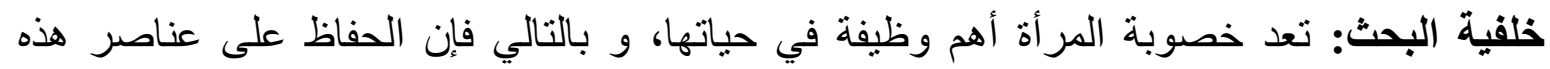

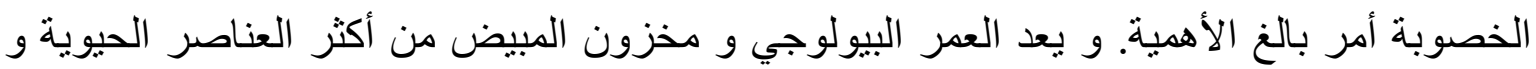

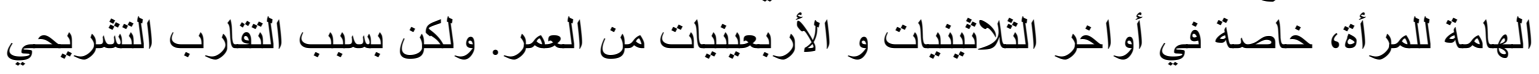

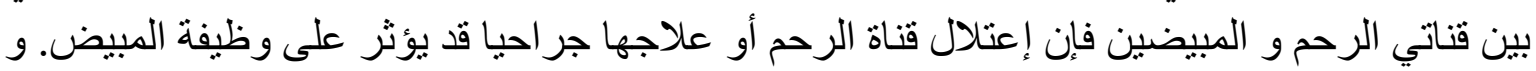

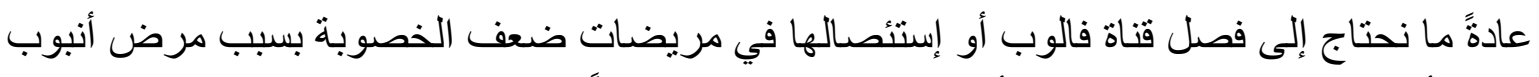

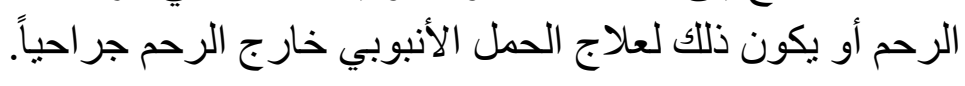
الهذف من البحث: دراسة نأثير فصل قناة فالوب أو إستئصال قناة فالوب بالمنظار البطني على العى

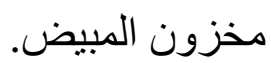

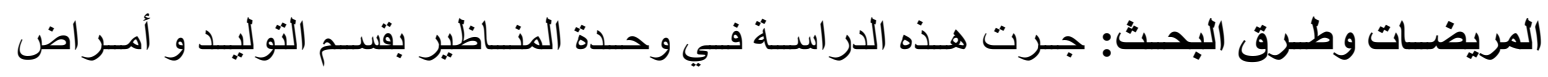

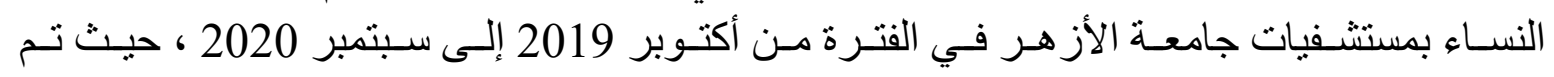

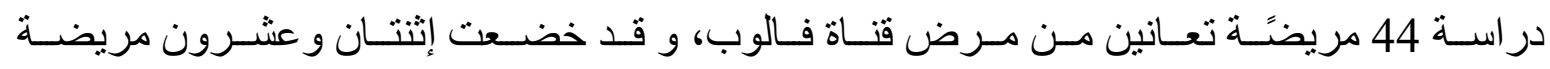

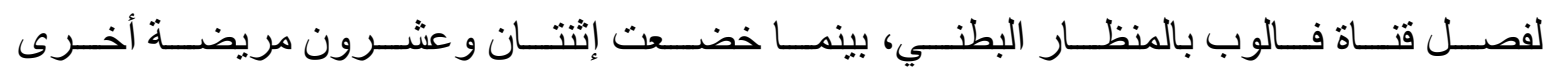

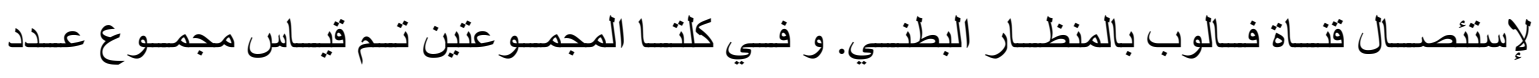

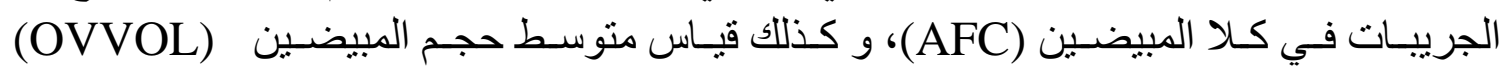

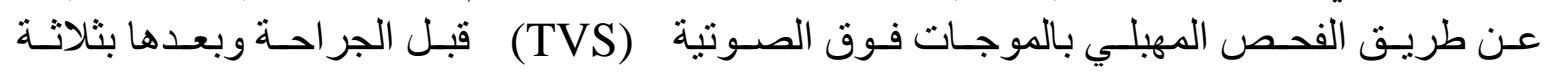
أشهر.

نتـائج البحث: لـم يختلف متوسـط مجمـوع عدد الجريبـات ومتوسط حجم المبيضـين قبـل وبعد

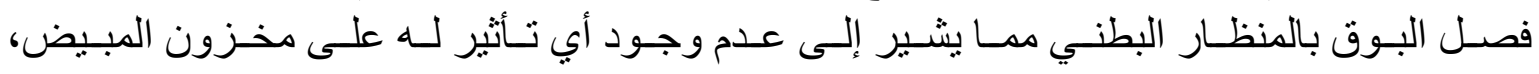

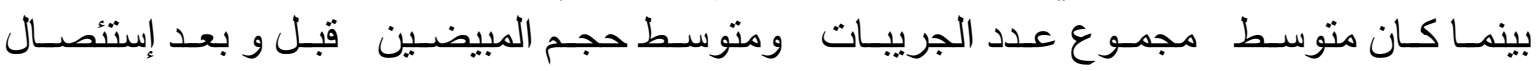

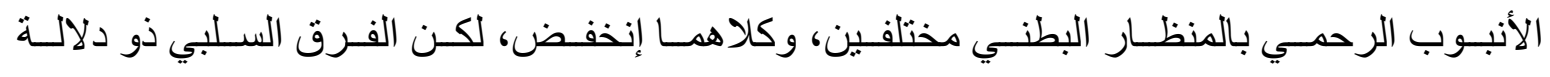

إحصائية في متوسط حجم المبيضين فقط.

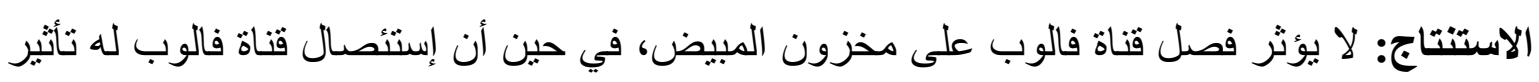

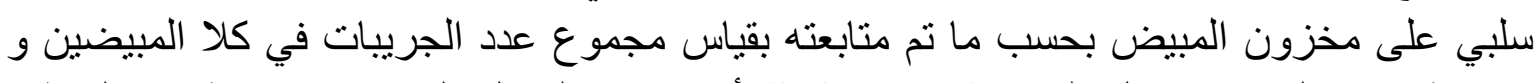

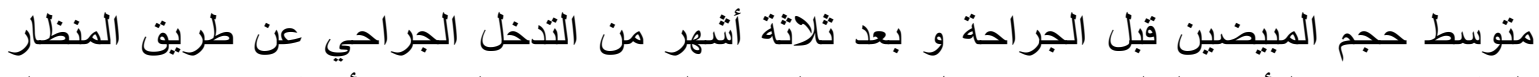
البطني. وهذا الثأئير السلبي لإستئصال قناة فالوب علي مخزون المبيض أعطي قيمة ذاث دلالة 
إحصائية عند قياس منوسط حجم المبيضين فقط، ولم يعطِ قيمة ذات دلالة إحصائية عند قياس مجموع فئر عدد الجريبات في كلا المبيضين.

الكلمات الالةة: مخزون المبيض، عدد جريبات المبيض، حجم المبيض، فصل قناة فالوب، إستئصال قناة فالوب، المنظار البطني. 